\section{Distances at which Sounds of Heavy Gun-firing are} Heard.

IN NATURE of September $30 \mathrm{I}$ see a letter from Dr. Henry de Varigny on the above subject. It reminds me of September 2 last year, when I noted in my diary :- "The day here (400 ft. elevation on scarp of the Lower Greensand overlooking the Weald) was brilliantly fine and warm, without a cloud, South Downs misty, a gentle wind from the south-eastward. My sister heard very distant continuous rumbling, like guns, all the morning up to I.30, and several times mentioned it when sitting in the garden; my coachman and a maid-servant also heard it. What was going on that day in France it would be interesting to know; there was no gun-firing on the coast of Sussex." I wrote, after taking bearing on map :"It may possibly be as far as I 50 miles to Amiens." I find twice since, and only a fortnight ago, similar continuous rumbling has been heard, but unfortunately the date not noted. I am much too deaf to hear such sounds myself.

Nore, Godalming, October I.

THE only papers on this subject with which I am acquainted are the following:-(I) The distance to which the firing of heavy guns is heard, NATURE, vol. lxii., 1900, pp. $377-79$; (2) the audibility of the minuteguns fired at Spithead on February 1, Knowledge, vol. xxiv., rgor, pp. 124-25. Reference might also be made to Nature, vol. xli., I89o, p. 369, and vol. 1x., I899, p. I39. The firing during the funeral procession of the late Queen Victoria was heard to a distance of I39 miles from Spithead. There is therefore no reason why firing along the Belgian coast should not, with favouring winds, be heard for many miles inland from our coasts. The air-vibrations affect pheasants and other birds (probably by swaying the branches of trees) for some distance after they cease to be perceptible to the human ear, as was widely observed on the occasion of the North Sea battle on January 24. I would suggest that observations of this kind should also be forwarded to Dr. de Varigny.

I may add that the literature relating to explosions is more extensive and much more valuable than the above. Prof. Omori's memoirs on the eruptions of the Asama-yama (Bull. Imp. Earthquake Inves. Com., Tokyo, vol. vi., I912, pp. I-147, and vol. vii., I914, pp. $\mathrm{I}_{-2} \mathrm{I}_{5}$ ) contain many interesting observations. A few cases of recent explosions in factories are noticed in Nature, vol. Ixi., 1899, pp. 91-92, and Knowledge, vol. i., 1904, pp. 94-95. Mr. S. Fujiwhara has lately published a valuable memoir on the abnormal propagation of sound in the atmosphere (Bull. of the Centr. Meteor. Obs. of Japan, vol. ii., pp. I-r43). This contains a mathematical discussion of the problem, with special reference to the observations recorded by Prof. Omori. References to recent German literature on the subject are also to be found in this memoir.

I6 Manor Road, Birmingham. Charles Davison.

\section{The late Prof. E. A. Minchin on "The Evolution of the Cell."}

Prof. E. A. Minchin was looking forward with interest at the time of his death to distributing the "extra prints" of his Manchester address, which was three times as long as will appear in Nature. These "extras" are now in my possession, but I have no means of getting Prof. Minchin's "list." I shall be very happy to send a copy to anyone who will send me a postcard asking for it.

Edward Heron-Allen.

Large Acres, Selsey Bill, Sussex, October 12. NO. 2398, VOL. 96]
DEATH FROM STATIC CHANGES IN ATMOSPHERIC PRESSURE.

$A \mathrm{~S}$ mentioned in a note in Nature of July 8

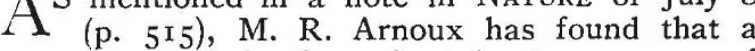
momentary diminution of at least $35^{\circ} \mathrm{mm}$. of mercury in barometric pressure may be produced within three metres of a bursting high-explosive shell; and he suggests that the sudden diminution of pressure may cause death by the liberation of gas-bubbles in the blood, and consequent blocking of the circulation.

In his book on "La Pression Barométrique," published nearly forty years ago, Paul Bert proved that the various symptoms which often follow decompression from high atmospheric pressure are due to liberation of gas-bubbles in the blood or tissues. In diving work, and various $\mathrm{k}$ inds of engineering work under water or in water-bearing strata, men are exposed to high atmospheric pressure. During the exposure the blood passing through the lungs takes up in simple solution an extra amount of gas in proportion to the increased partial pressure of each gas present in the lung air. The gases present are oxygen, carbon dioxide, and nitrogen. The extra free oxygen taken up is, however, very small in amount as compared with the total free and combined oxygen taken up at normal atmospheric pressure; and since much of this total is used up as the blood passes through the tissues, there is no appreciable rise in the very low partial pressure of oxygen in the blood of the systemicapillaries or veins or in the tissues. There is also no rise in the low partial pressure of carbon dioxide in the lung air or blood, since the breathing is so regulated as to maintain a practicaliy constant partial pressure of carbon dioxide in the lung air. On the other hand, the partial pressure of nitrogen in the blood leaving the lungs rises in proportion to the increased atmospheric pressure, and as no free nitrogen is used up, every part of the body becomes gradually saturated with nitrogen at this increased partial pressure. If, now, the atmospheric pressure is again reduced to normal, the blood and semiliquid tissues of the body are left in a condition of super-saturation with nitrogen, and as a consequence bubbles, consisting almost entirely of nitrogen, are apt to form, and to cause very serious effects. Death may result from blockage of the circulation through the lungs or heartmuscle; paralytic attacks may be caused by blockage in the brain or spinal cord; while characteristic localised pain (so-called "bends") may be produced by the presence of bubbles elsewhere.

It is clear that if the atmospheric pressure is considerably diminished from normal, a similar condition of super-saturation of the body with nitrogen will exist, so that bubbles may be formed; and it is natural to suspect that a sudden, though only momentary, diminution, due to the bursting of a shell, might liberate bubbles. There are, however, facts which tell strongly against this hypothesis.

In the first place, it must be pointed out that 